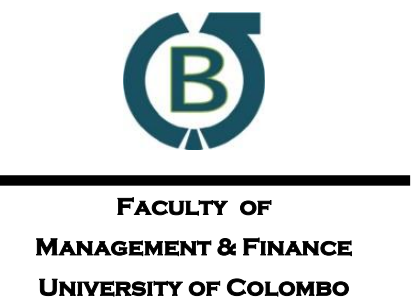

Colombo

Business

Journal

UNIVERSITY OF COLOMBO

INTERNATIONAL JOURNAL OF

THEORY \& PRACTICE

Vol. 09, No. 01, June, 2018

\title{
Entrepreneurial Personality: A Configurational Approach
}

\author{
Jose Mathews $\mathbf{a}^{\mathrm{a}} \bowtie$ \\ ${ }^{a}$ Gaeddu College of Business Studies, Royal University of Bhutan, Bhutan
}

\begin{abstract}
Entrepreneurial personality research can be said to be at crossroads as researchers are unable to formulate an approach that has predictive and explanatory powers. The developments in personality research have prompted entrepreneurial personality researchers to suggest a model that is capable of explaining the structure and processes of entrepreneurial personality. The configurational model suggested in this paper draws upon the trait dynamics and the Cognitive-Affective Personality System theory of personality reflecting the features of a total system view of entrepreneurial personality that clearly differentiates the patterns of entrepreneurial and non-entrepreneurial behaviours. Trait theory and the Cognitive-Affective Personality System theory variables delve into the deeper psychological processes to identify the basic structure and the processes of entrepreneurial personality. The configurational dynamics espouse the general pattern of entrepreneurial personality in an interactive and mediating relation among the intraindividual structures including the situation. The configurational dynamics further identify and differentiate the specific entrepreneurial personality constructs that researchers and practitioners frequently refer to.
\end{abstract}

Keywords: Entrepreneurial Personality, Entrepreneurial Cognition, Entrepreneurial Emotion, Entrepreneurial Motivation, Entrepreneurial Traits

Received:

11 October 2017
Accepted revised version: 03 April 2018
Published:

30 June 2018

Suggested citation: Mathews, J. (2018). Entrepreneurial personality: A configurational approach. Colombo Business Journal. (9)1, 45-79

DOI: http://doi.org/10.4038/cbj.v9i1.22

(C) 2018 The Authors. This work is licenced under a Creative Commons Attribution 4.0 International Licence which permits unrestricted use, distribution, and reproduction in any medium, provided the original work is properly cited.

凶josmathews@gmail.com; iD https://orcid.org/0000-0002-4503-6088 


\section{Introduction}

Entrepreneurs who form a minor segment of the society are differentiated from non-entrepreneurs who constitute the major chunk of the population. The uniqueness with which entrepreneurs are endowed with has been the subject of a number of studies especially in the area of personality. It is agreed by researchers that the essence of understanding entrepreneurship from a subjective perspective (Vaghley \& Julien, 2008) is through an in-depth examination of the structure and functioning of the personality patterns of entrepreneurs.

The research efforts made in this direction generally produced no conclusive explanation of personality as the focus of most of the research was rather diffused in understanding the total personality system of an entrepreneur (Korunka, Frank, Lueger, \& Mugler, 2003). More specifically, the constricted use of the trait approach to interpret entrepreneurial personality reached nowhere as researchers were not able to identify a consistent and coherent cluster of traits constitutive of entrepreneurial personality (Rauch \& Frese, 2007; Zhao, Seibert, \& Lumpkin, 2010).

Obschonka and Stuetzer (2017) contend that

the focus on the individual as a dynamic system characterised by both stability and plasticity and intra-individual dynamics between the more stable and the more malleable components, which have become a leading perspective in modern psychological science, is indeed largely missing in contemporary entrepreneurship research (in personality). ( p.204)

The intra-individual processes derived to explain personality in psychology range from cortical arousal (neurological explanation) (Matthews, 2016), which is not considered here, to dynamic structures and processes of cognition, emotion, traits and motivation (Mischel \& Shoda, 1995; Obschonka \& Stuetzer, 2017). Conceptualising a total system view of entrepreneurial personality involves the consideration of intra-individual structures and processes (including the Big Five Factors) and the situation which are found to be more basic to personality in differentiating an entrepreneur from a non-entrepreneur (Brandstatter, 2011; Obschonka \& Stuetzer, 2017).

This lacuna of a fragmented approach to the explanation of entrepreneurial personality can be corrected by following the Cognitive-Affective Personality System theory (CAPS theory) that systematically accounts for the intra-individual 
sub-systems and the psychological features of the situation in the experience of personality. CAPS theory, which also draws upon the social cognitive theory (Bandura, 1978) adopts a person-situation interactional approach to explain the structure and function of a person's consistent and variable behaviour patterns (Mischel \& Shoda, 1995). The significance of the situation, which is generally overlooked in trait explanations, is well integrated with the CAPS theory of personality where "situation -behaviour profiles show how a particular individual's behaviour pattern across the situation differs from the normative pattern of behaviour variation across them" and what at times differentiate the behaviour is the psychological features of the situation (Mischel \& Shoda, 1995, p.249).

Entrepreneurial personality researchers who go by the trait dimensions (for example, Brandstatter, 2011; Obschonka \& Stuetzer, 2017) state that traits cause behaviour, "traits are viewed as causes of mental and behavioural processes" (Brandstatter, 2011, p.223). In the same vein, Brandstatter (2011, p.223) states that "nothing is said about the mental and behavioural processes by which these traits influence start up decisions and entrepreneurial success". In other words, how traits cause mental and behavioural processes can be explained by delving into the cognitive, affective and motivational processes which give rise to the formation of stable entrepreneurial behaviours, otherwise called entrepreneurial personality (Brandstatter, 2011; Mischel \& Shoda, 1995; Obschonka \& Stuetzer, 2017).

Deriving a coherent, holistic and total system view of entrepreneurial personality thus involves explaining the interaction and the mediation that go into the development of entrepreneurial personality and this takes one to a configurational approach to understanding entrepreneurial personality.

The configurational approach (Meyer, Tsui, \& Hinings, 1993; Miller, 1987) which relates to interconnected structures and processes take a holistic and dynamic view in its consideration of a phenomenon. A configuration involves the consideration of a "constellation of conceptually distinct characteristics that commonly occur together...processes, practices, beliefs and outcomes have been said to cluster into configurations" (Meyer et al., 1993, p.1175). In differentiating structures and processes, the configuration mode refers to constructs which are structures and processes which link constructs together (Dauber, Fink, \& Yolles, 2012). The inter-connected intra-individual forces and situational features can produce a configuration that defines the dynamic nature of an entrepreneurial 
personality. Alternatively the same structures and processes which differ in their nature and processes can produce a non-entrepreneurial personality.

Casting entrepreneurial personality in the configurational perspective circumvents the limitations imposed by the correlational and the unidirectional approaches followed in the earlier approaches to entrepreneurial personality. This better explains the pattern of entrepreneurial behaviours which are the outcomes of an interactional approach (Meyer et al., 1993) where the structures and processes are the causes and the configuration is the effect - entrepreneurial personality (Miller, 1987). Besides depicting the interactional and the interrelationships among the core internal and external processes and structures of entrepreneurial personality, the configurational approach also accounts for the related specific entrepreneurial personality constructs which are considered as offshoots of the basic structure of the entrepreneurial personality. The paper thus delineates how the intraindividual entrepreneurial structures and processes and the situations configure an entrepreneurial personality generally and specifically wherein the general configuration points to the overall effect of the intra-individual and situational variables and the specific configuration indicates the effect due to the interaction of certain specific variables in the configurational dynamics.

\section{Conceptual Background of the Study}

In this section a review of the personality literature and entrepreneurial personality research is presented, which is followed by the exposition of the theoretical framework of the proposed model of entrepreneurial personality.

\section{Entrepreneurial Personality (EP): The Extant Literature}

The concept of EP is derived from entrepreneurship and personality. Entrepreneurship is equated with innovative and value-creation behaviours (Leutner, Ahmetoglu, Akhtar, \& Chamorro-Premuzic, 2014) besides relating it with recognition, evaluation and pursuit of an opportunity in different contexts (Pendergast, 2003). Examining the concept of EP in the context of personality leads one to the consideration of the interpretation of personality where the general position is that personality of an individual refers to the psychological forces that make individuals unique, distinctive and consistent in different situations of interaction (Baron, 2001). Researchers go by the general position that personality is an individual's unique and relatively stable patterns of behaviour, thoughts and 
emotions (Baron, 2001). EP thus relates to the characteristic thought, feelings and behaviour patterns of an entrepreneur who creates new values in an entrepreneurial context (Ostergaard, 2014).

The earliest versions of EP research are equated with personality traits research (Korunka et al., 2003) where traits can be defined as stable inner dispositions determining the behaviour. The traits that make-up EP include need for achievement, internal locus of control, persistence, determination, risk-taking, and independence (Pendergast, 2003).

However, EP research fell into disrepute due to a number of reasons, the major being the inconclusive results that did not go beyond certain correlates between entrepreneurship and personality (Zhao et al., 2010) and in this, entrepreneurial processes were oversimplified by relating it to certain random personality traits. Secondly, personality traits are not strongly related to entrepreneurship to warrant further studies, and thirdly, alternate views such as ecological approaches which focus on environmental accounts have been proposed to account for individual variations (Rauch \& Frese, 2007). Further, the trait approach to EP was abandoned because of the prevalence of multiple theories and approaches to explain the stable personality structures and dynamic inner processes that reflect stylistic consistencies in behaviour in the versions of bidirectional and interactional models of personality (Bandura, 1999; Chell, 2007; Mischel \& Shoda, 1995; Obschonka \& Stuetzer, 2017).

The revival of interest in EP is also found in the views that trait dispositions are to be studied in relation to the situation that increases the predictive power of traits and in the integration of newer and more encompassing models of personality (Korunka et al., 2003; Rauch \& Frese 2007). The use of newer approaches to study personality like the social-cognitive view and/or the person situation interactional models has brought about significant developments in this area (Bandura, 1999; Mischel \& Shoda, 1995; Obschonka \& Stuetzer, 2017).

Additionally, increased interest in the role of personality in entrepreneurship has recently seen resurgence due to the application of advanced research designs like the meta-analysis and factor analytical approach to traits (Rauch \& Frese, 2007; Zhao et al., 2010). Elaborating on the significance of meta-analytic studies that group number of findings, Hunter and Schmidt (1990) contended that findings 
which were made redundant due to methodological problems were corrected producing significant findings urging new research to uncover the internal and external dynamics of the personality of the entrepreneur.

The two predominant views in the current theory and practice of personality, the factor analytic trait approaches and the interactionist perspective (Baron, 2001; McCrae \& Costa, 2008; Mischel \& Shoda, 1995) deserve special consideration as they are the two cornerstones of EP as considered here. According to McCrae and Costa (2008) traits are implied in the consistent and recurring patterns of acting and reacting that simultaneously characterise and differentiate individuals from others. In describing personality as a dynamic psychological organisation of the psychphysiological systems, the trait theorists turn to considering the personality system that consist of components and the dynamic processes that interrelate the components. In accordance with the Five Factor Theory of McCrae and Costa (2008) the basic tendencies of Extraversion, Neuroticism, Openness to Experience, Agreeableness and Conscientiousness are the core traits that show themselves up in personality.

In the interactionist view, the stable internal structures and processes of cognition, affect, traits and motivation characterise individuals as unique entities (Mischel \& Shoda, 1995). In this perspective, personality is a complex organisation of these internal structures and processes that are in interaction with the situation and the complexity is understood in terms of the dynamic interactions between/among these components.

The contemporary theories of personality and EP are dominated by the mediating process models of cognition (Bandura, 1999; Mischel \& Shoda, 1995) affect (Mischel \& Shoda, 1995) motivation (Brandstatter, 2011; DeShon \& Gillespie, 2005; Mischel \& Shoda, 1995) traits (McCrae \& Costa; Obschonka \& Stuetzer, 2017) and situation (Bandura, 1999; Mischel \& Shoda, 1995; Sarason, Dean, \& Dillard, 2006). As such a model of EP must draw upon the mediating structures and processes which are found to be the basic tendencies and underlying mechanisms of EP (Mischel \& Shoda, 1995; Obschonka \& Stuetzer, 2017).

The situation enters the interactive-mediating process as the features of the context are 'generated in thought, planning, fantasy, and imagination' and the context can also become an intra-psychic process (Mischel \& Shoda, 1995). The context becomes integrated with the other mediating processes as they continue to 
influence each other in the dynamic process of a reciprocal interaction (Bandura, 1978; Levy, Beechler, Taylor, \& Boyacigiller, 2007). It is this perspective of personality as a system of interacting and mediating variables of the internal systems and the external attributes of the situation that enable a researcher to predict and explain EP.

\section{Theoretical Framework of the Proposed Model}

Having surveyed the general nature of EP research and the current interpretations of personality, the next step is to find a holistic, dynamic and a total system view of EP that integrates the predominant trends of interactionism and trait approach in personality and EP research.

Attempting to suggest a total-system view of personality involves drawing inputs from the trait models of EP, social cognitive theory and the CAPS theory of personality. The Five Factor Theory of personality considers traits as the basic tendencies that have biological bases of neurological processes which are stable and enduring tendencies (McCrae \& Costa, 2008). Moreover, as 'abstract psychological potentials' and 'deeper psychological entities' they have strong and continuing influence on the behaviour and they fashion the personality. In the same vein the CAPS theory that accounts for personality invariance in its identification of the basic structures and processes, mark the cognitive, affective and motivational units along with traits which are organised subjective structures and processes activating behavioural patterns. However, in CAPS theory and related views (for example Brandstatter, 2011) traits are psychologically based at the cognitive - affectivemotivational processes and traits are derivations of these basic psycho-neurological processes (Mischel \& Shoda, 1995). Traits here become an outcome and a differentiating psychological structure that directly influences behaviour.

In relation to this total system view of personality, it can be stated that EP structures and processes are to be understood relating the intra-individual processes of Cognition, Affect, Motivation, Traits, and the Situational processes (CAMTS) which in its interactive-mediational processes "operate as interlocking determinants of each other" (Bandura, 1978, p.346) that finally differentiate a personality or for that matter an entrepreneurial personality from a non-entrepreneurial one (McCrae \& Costa, 2008; Mischel \& Shoda, 1995; Obschonka \& Stuetzer, 2017). The individual differences that personality researchers are concerned about are found in these differentiated and interacting inner sub-systems and the external/situational context which are in a state of active reciprocal relations (Bandura, 1978; Chell, 
2008; Mischel \& Shoda, 1995; Obschonka \& Stuetzer, 2017). However, in the finer differentiation, reciprocal relation is not always a given as there can be nonreciprocal interaction and it depends on the inputs and the mediating units, which in other words means that it is the configurational dynamics that ultimately determine the personality patterns (Mischel \& Shoda, 1995). Thus, CAMTS in its dynamic, interactional and configurational nature become the core processes of EP.

In this person-situation interaction theory EP is conceptualised as a dynamic psychological organisation of internal and external forces (Baron, 2001; Mischel \& Shoda, 1995; Obschonka \& Stuetzer, 2017) of Cognition, Affect, Motivation, Traits and the Situation leading to the source of variation in personality (Bandura, 1978; Chell, 2008; McCrae \& Costa, 2008; Mischel \& Shoda, 1995). In an equation form $\mathrm{EP}$ is expressed as $\mathrm{EP}=\mathrm{f}[\mathrm{C}, \mathrm{A}, \mathrm{M}, \mathrm{T}, \mathrm{S},(\mathrm{C} \times \mathrm{A} \times \mathrm{M} \times \mathrm{T} \times \mathrm{S})]$ wherein the interaction implies the combined effect of CAMTS in determining EP (Chell, 2008). The (reciprocal) multidirectional interactions among these system variables characterise the personality of the individual or the EP. It can be surmised that each intraindividual process is an interactive outcome of the other interacting processes, that, for example $\mathrm{C}$ is an interactive outcome of A M T and S.

In the interactive-mediating explanations of EP drawn upon the general personsituation approach to personality, the focus is on the "psychological mediating processes" (Mischel \& Shoda, 1995, p.252) of CAMTS brought in by both socialcognitive theory of Bandura (1999) and the CAPS theory wherein the mediating processes of cognition, affect, motivation and traits, which together with the situation interact and generate "distinctive complex molar behaviour patterns" (Mischel \& Shoda, 1995, p.252) of entrepreneurial nature. These mediating processes are represented by an individual's encodings or construal (of self, others, people, situations), expectancies or beliefs (about outcomes and one's own efficacy); affects (feelings, emotions); subjective values; competencies (for the construction and generation of social behaviour); motivation-self-regulatory strategies and plans in the pursuit of goals and activated trait dispositions (Mischel \& Shoda, 1995; Obschonka \& Stuetzer, 2017).

In the same way an individual structures a situation, the situation also structures the behaviour of the individual which is explained by the reciprocal relations theory, CAPS theory and structuration theory. The pattern of reciprocal relations between situation and intra-individual processes is a foregone conclusion in the socialcognitive theory of Bandura (1978) and related theories (Dess, Newport, \& 
Rasheed, 1993; Levy et al., 2007; Korunka et al., 2003; Mischel \& Shoda, 1995; Sarason et al., 2006) even though, as stated above, it is not always active depending on the configurational patterns (Mischel \& Shoda, 1995). The situation interacts with the internal structures and processes wherein these five factors configure (Dess et al., 1993; Korunka et al., 2003) the EP system such that intra-individual dynamic processes in interaction and integration with the situation (Mischel \& Shoda, 1995) capture the nature of the EP system.

\section{The Configurational Model of Entrepreneurial Personality System}

The general configurational approach suggested by the author depicted in Figure 1, is derived from the interactive-mediating explanation of EP which is in keeping with the dynamic organizational structure of personality where the intraindividual subsystems and the situation constitute the configuration that can vary from context to context or from person to person.

Figure 1: The General CAMTS Configuration Model of Entrepreneurial Personality

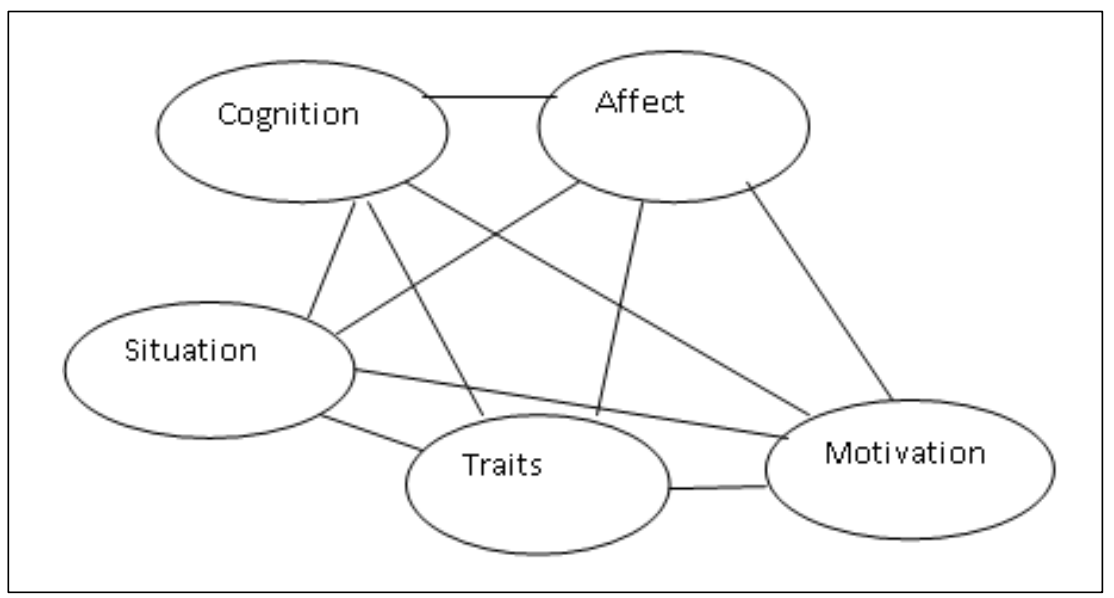

The patterns of behaviour that characterise the EP are in the configuration of intra-individual processes and situational variables of importance (Connell, Halpem-Felsher, Clifford, Crichlow, \& Usinger, 1995; Korunka et al., 2003). In the configurational approach the dynamic psychological structures and processes configure the personality pattern (Mischel \& Shoda, 1995; Korunka et al., 2003) that goes beyond the unidirectional influences and focuses on "patterns and interrelations within a broader set of configuration areas" (Korunka et al., 2003, p.25) wherein the configurations are understood as inherently multidimensional in 
nature where key attributes are tightly interrelated and mutually reinforcing (Korunka et al., 2003). A configuration can represent a number of specific and separate processes and dynamics connected to attributes which are meaningful collectively rather than individually and it represents a relatively long-lined set of dynamics representing multiple domains (Dess et al., 1993). In this configurational approach the significance of each subsystem varies in different combinations and the five variables differentially pattern the behaviour. The configuration of these forces changes in response to adaptive functioning (Dess et al., 1993) or in accordance with the impact of a particular force, as for example, when the influence of situation is predominant or when it is least influential in determining the behaviour (Mischel \& Shoda, 1995). It is these multiple (reciprocal) interactions of dynamic and continuing nature that characterise the configurational process of entrepreneurial personality.

\section{The Interactional Dynamic Processes}

Cognitive-affective states are intertwined and they mutually influence each other in generating cognitions and emotional states. Affect and cognition co-exist, and they independently and in an interactive way influence each other in generating behavioural processes (Homburg, Koschate, \& Hoyer, 2006). According to Baron (2008) affect influences cognition in the process of perceptions of the external world, in stimulating creativity, in the tendency to engage in heuristic processing, in memory, in the use of cognitive strategies and in the interpretation of other's motives. In the same way, affect influences cognition, cognition also influences the affective dynamics (Baron, 2008). Cognition, behaviours, motivation and affect are interrelated and interacting such that according to Schunk and Zimmerman (1994), cognitions, behaviours and affects are activated and oriented toward the goal attainment, which then becomes a motivational process.

The importance and the significance of considering interactions among the subsystems are further expressed by Lazarus (1991) where he states that

without cognitive activity to guide us we could not grasp the significance of what is happening in our adaptational encounters with the environment, nor could we choose among alternative values and courses of action. Emotion without thought would be mere activation without the directionally distinctive impulses.... Motivation without cognition would be merely a diffuse undifferentiated state of activation...Finally integration of behaviour would also be impossible without cognitive direction. (p.352) 
The interrelationships and interactions among the inner sub-systems are also expressed in what is called Action -Trait theory (A - T theory). This grand theory of motivation deals with the "what" and "how" of motivation, where "what" involves, a taxonomy of states and outcomes and "how" is an interaction and interrelationships of cognition, emotion and behaviour that emerge "as they affect the manner in which desires (wants) are experienced (externalized)" (Bernard, 2016, p.24).

Further support for the interactions between sub-systems, can be identified in the literature that discusses relationships between traits, motives and context. Traits mediate the expression of motives or goal-directed behaviours (Brandstatter, 2011) and the interactive effects of motives and traits greatly explain behaviour than when they are considered independently since many trait theories conceive of traits as having motivational components (Winter, John, Stewart, Klohnen, \& Duncan, 1998) and "it seems justified to deal with the Big Five and the motives in the same vein" (Brandstatter, 2011, p. 223). Traits are also greatly understood in relation to the context and the person situation interaction model specifies the uniqueness of situation in the activation of trait dynamics (Mischel \& Shoda, 1995).

The reciprocal interactions between the personality subsystems and the context are explained by the structuration theory which states that in the recursive relationships the sub-systems and the context influence each other in the processing of the information of attributes (Levy et al., 2007; Sarason et al., 2006)). In the entrepreneurship context, Sarason et al. (2006), refer to the mechanisms of cocreation where the entrepreneur and the context are in a relationship of duality.

From the contextual angle, a particular situational feature activates certain units which activate other related units "until ultimately they generate a behavioural response" (Chell, 2008, p.150) and the crux of the dynamic process interaction model of the five factor model of entrepreneurial personality is multiple (reciprocal) interactions leading to the emergence of a configuration that generally defines EP and specifically defines individual entrepreneurs. The CAMTS systems thus "interact dynamically and influence each other reciprocally (or otherwise) and it is the organisation of the relationships among them that form the core of the personality structure" (Mischel \& Shoda, 1995, p.253) or EP (Obschonka \& Stuetzer, 2017). 
The general pattern of EP in Figure 1, delineates the multiple (reciprocal) determinations of the sub-systems which, as indicated by the lines, configure an EP. The configurational dynamics that characterise EP collectively influence each other, such that CAMTS in its interaction and mediation, configure general EP pattern and specific EP patterns. This principle of the interaction, mediation, and activation or deactivation of the mediating units is in keeping with the reciprocal determinism view of Bandura (1978) and CAPS theory of Mischel and Shoda (1995) that characterise the subsystems of differential nature for each person.

The general pattern of configuration conforms to the personality of entrepreneurs where all entrepreneurs regardless of their variations fit in and to explain the within-variations of entrepreneurs one has to invoke the specific configurational dynamics of EP. This is because the activation of a mediating unit and the effects it produces are traced to the particular individual-specific CAMTS (Mischel \& Shoda, 1995).

In the general and specific multiple (reciprocal) interactions that configure the functional relationships between/among the subsystems, the differentiating personality patterns are explained "in terms of whether and when they become, in varying degrees, activated, deactivated or are not influenced by each other" (Mischel \& Shoda, 1995, p.255) producing predictable behaviours in a given configuration. Accordingly, the interactions can be reciprocally active, reciprocally deactive, one way active, one way deactive and/or zero influence. An example of these patterns of interaction leading to a particular configuration is shown in Figure 2 where, for example, cognitions influence emotions (one-headed arrow), cognitions and emotions influence each other (two-headed arrow), cognitions and situation do not influence each other (two headed dashed arrow) cognitions and motivation influence each other (two-headed arrow) and cognitions either have least influence on trait activation or deactivate traits (dashed one-headed arrow). In the same way, other patterns of interactions of one way, two-way or least influence between two or more subsystems that configure EP can be depicted for other configurations of affect, motivation, trait and situation. These differential patterns of influences of activation and/or deactivation (least influence to zero influence to inhibition) which are traced to the individual's own unique mediating units, determine the extent of entrepreneurial behaviours or the "signatures of personality" (Mischel \& Shoda, 1995, p.248). 
Figure 2: A Model of Specific Configuration of Entrepreneurial Personality

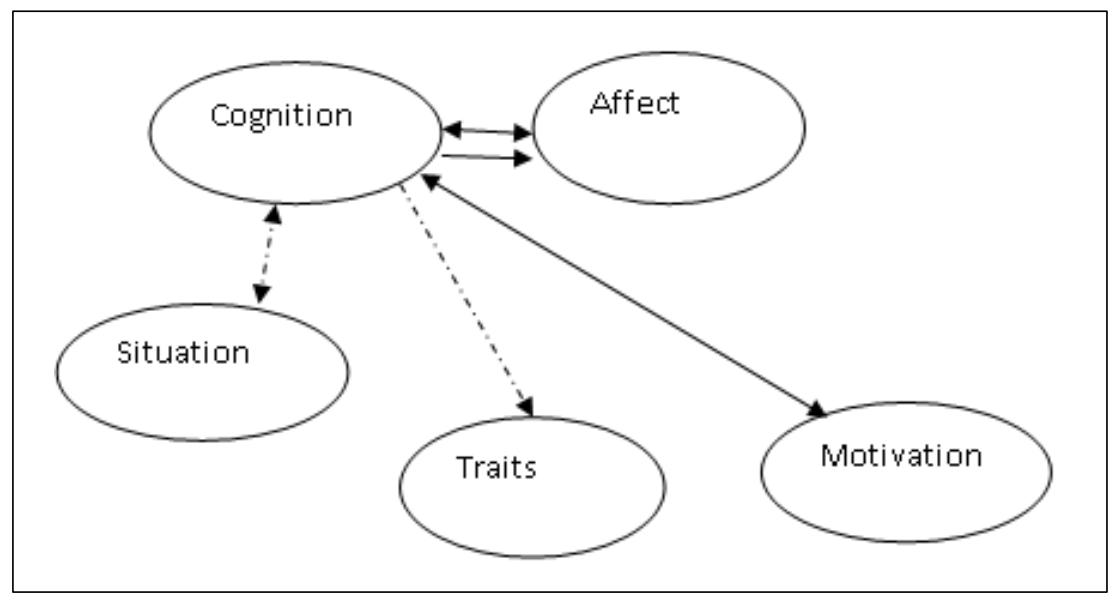

Now the pertinent question is how does one characterise the intra-individual subsystems of multiple interactions that activate or deactivate the specific and general patterns of entrepreneurial behaviours (Mischel \& Shoda, 1995), or in other words what differentiates the subsystems of entrepreneurs and non-entrepreneurs? The answer is given in the explanations of the nature of the sub-systems.

\section{Entrepreneurial Cognitions}

Entrepreneurial cognitions that differentiate an entrepreneur from a nonentrepreneur form one of the five basic mediating and sub-system units of the configurational model of personality. Cognitions that involve thoughts, beliefs, knowledge, expectancies, goals and desires are characterised by the intentional, computational and representational processes of transforming, reducing, elaborating, storing, recovering and using the sensory information (Madhavaram, Badrinarayanan, \& Granot, 2011; Neisser, 1967). The structures and processes of cognitions involved in the generation of cognitions are respectively called cognitive structures and cognitive processes (Schneider \& Angelmar, 1993). Cognitive structures are different forms of representations of knowledge that differ in the degree of differentiation, articulation and integration of knowledge units labelled cognitive complexity (Levy et al., 2007; Schneider \& Angelmar, 1993). The greater the complexity of the cognitive structure, the higher the information-processing capability and highly complex cognitive structures stores and uses loads of information in cognitive processing activities producing innovative/problem-solving outcomes (Levy et al., 2007). Cognitive processes refer to the search, selection and retention involved in information processing (Schneider \& Angelmar, 1993). 
Entrepreneurial cognitions, are "knowledge structures that people use to make assessments, judgments or decisions involving opportunity evaluation, venture creation and growth" (Mitchell et al., 2007, p.2). Entrepreneurial thinking is understood in terms of opportunity recognition and as a cognitive process it differs among individuals. According to Shane and Venkataraman (2000), discovery of opportunities differ among individuals because of the two reasons of the possession of prior information necessary to identify an opportunity and the cognitive properties necessary to value it.

The cognitive properties of the cognitive structure of individuals differ and entrepreneurs generally share certain features. Mitchell, Smith, Seawright, and Morse (2000) state that entrepreneurial cognitions vary systematically in comparison to non-entrepreneurs. In their exposition, Mitchell et al. (2000) refer to the prevalence of expert scripts/cognitive scripts which are active in entrepreneurial thinking. Also, these scripts are considered to be the cognitive bricks and mortars of building new ventures.

These expert scripts of a dynamic process are knowledge structures organised in long-term memory through the "iterative interrogation, instantiation and falsification of cognitions grounded in real-world experience" (Mitchell et al., 2000, p.975). These scripts can relate to arrangement cognitions of the feasibility of a venture, willingness cognitions of the propensity to act and ability cognitions of the venture desirability, which are otherwise termed arrangement scripts, willingness scripts and ability scripts, respectively (Mitchell et al., 2000).

The development of entrepreneurial cognitions involve the information processing that can involve the three phases of attention (or information acquisition), interpretation and action (Daft \& Weick, as cited in Levy et al., 2007). Cognitive structures mediate the information processing and the specific nature of the cognitive structure besides the complexity aspect and individual-specific propensities, influences the way processing of information is executed.

In the information processing perspective opportunity identification takes two dichotomous interpretations: entrepreneurial opportunity is viewed as objective: exogenous, discovered, exclusive, centred on the entrepreneur and on the entrepreneur's information network and on the other side it is subjective: endogenous, enacted, inclusive, cognition based, centered on the entrepreneur and the way information is processed (Vaghley \& Julien, 2008). 
The former viewpoint is termed opportunity discovery or recognition and the latter is termed opportunity enactment or construction (Vaghley \& Julien, 2008). This duality view of entrepreneurial information processing pursues formal models or algorithms (opportunity discovery/recognition) and interpretative or heuristic models (opportunity enactment or construction) (Vaghley \& Julien, 2008).

The CAPS theory of personality underlines the individual-specific information processing where "individuals differ stably in the chronic accessibility or activation levels of the particular mental representations available to them" (Mischel \& Shoda, 1995, p.253). Accordingly individual-specific cognitive structures and processes differentiate an entrepreneur from a non-entrepreneur at the personality level (Baron \& Ward, 2004). The information processing and interactions "(generate) characteristic predictable patterns of variation as well as characteristic elevations in the individual's behaviour across situations" (Mischel \& Shoda, 1995, p.262).The information processing characterised by the complexity and the properties of the cognitive structures and processes produce cognitive outcomes which are distinctive and differentiating an entrepreneur.

\section{Entrepreneurial Emotions}

Entrepreneurial emotion, which is a subjective state of feeling or experience can be an antecedent to or/and concurrent with or/and a consequence of opportunity recognition or identification (Cardon, Foo, Shepherd, \& Wiklund, 2012). Emotion is intertwined with the entrepreneurial activity of opportunity recognition, or evaluation of the feasibility of an opportunity.

In the entrepreneurial process, according to Baron (2008), affect plays important roles in influencing the entrepreneurial activities. Firstly, by its very nature entrepreneurial activities are undertaken in an unpredictable environment and as such affect can readily tip the balance in the pleasant or in the unpleasant direction, both of which have consequences for the entrepreneurial outcomes. Experiences of failure can result in negative emotions and it can have destructive effects just as immoderate positive emotions produce negative effects (Wolfe \& Shepherd, 2015). In the same way, negative emotions managed in a realistic manner and positive emotions taken in a constructive manner produce positive effects (Wolfe \& Shepherd, 2015).

Secondly, the varied and novel tasks that entrepreneurs perform in starting new ventures are found to be influenced by affect. According to Baron (2008) affect 
comes into play in the entrepreneurial activities of creativity (opportunity recognition), persuasion (acquisition of essential resources), decision-making and judgment (setting up of business models and formulation of strategies) and formation of working relationships with others (leading others in goal accomplishment).

Having outlined the role of emotional experiences in entrepreneurship, it is useful to examine the application of Affective Events Theory (AET) in the emergence of an entrepreneur and/or in the creation of venture. Morris, Kuratko, Schindehutte, and Spivack (2011) examine the way entrepreneurial experiences are framed by applying the AET.

In accordance with the appraisal and the social construction theories of emotion, AET originally suggested by Weiss and Corpanzano (1996) suggest that appraisal of events in work and the contextual cues embedded in work situation produce affective reactions in individuals and entrepreneurship as a personal, temporal stream of experience involve unique and novel events rich in affect (Morris et al., 2011). In this stream, the individual-level factors of personality hold the key to the experience of entrepreneurial emotions which can be in the constructive or in the destructive path (Wegge, Dick, Fisher, West, \& Dawson, 2006).

In explaining further how individual entrepreneurs differ in their experience of affective events, one may resort to the basic tendencies of approach and avoidance which are largely posited in an "information processing basis of affect" that become the critical underpinnings of personality (Carver, Sutton, \& Scheier, 2000, p.744). Individuals differ in what researchers call Behavioural Activation System (BAS) and Behavioural Inhibition System (BIS) (Carver et al., 2000).

The entrepreneurial process implies that successful entrepreneurs can be differentiated in relation to their approach/avoidance tendencies. Gray (as cited in Carver et al., 2000), states that BAS responds to incentives-signals of reward, nonpunishment and escape from punishment which accelerates goal-directed behaviour whereas BIS responds to threats-signals of punishment, non-reward and novelty which decelerates movement towards goal-directed behaviour. In the emotional language, BAS is responsible for positive emotions and BIS accounts for negative experiences. Entrepreneurs with BAS tend to make greater gains in entrepreneurial activities and those with BIS tend to make losses. 
The generation and the experience of emotions or emotional reactions can be considered under the two perspectives of cognitive processing or social construction (Goss, 2008). In the cognitive processing view emotional experience is dependent on the appraisal of the impact of an event and in the social constructionist view the focus is on social contexts. Goss (2008) opines that in their 'strong' and 'weak' forms the appraisal theories and constructionist theories have produced revisions and variations to explain further the nature and the generation of emotional experiences which point to the fact that emotional experiences are interlaced with cognition, motivation, dispositions and context thereby producing an interactive experience which is individual-specific.

Emotions which are inextricably linked with the personality of the individual and the situation (Mischel \& Shoda, 1995) produce beneficial or harmful reactions in individual behaviour (Smith \& Lazarusas, as cited in Mischel \& Shoda, 1995). In the accompaniment of emotions of pleasant or unpleasant nature, the activities take on positive or negative outcomes and the experience of pleasant or unpleasant emotions are in accordance with the individual's own basic tendencies of approach and/or avoidance which again spills over to, say, entrepreneurial activities.

\section{Entrepreneurial Motivation}

In the configuration of the forces of personality, motivation too plays a significant role (Mitchellet al., 2007) as motives or motivational processes are core to the biological, cognitive and social regulation processes that enable the prediction of behaviour (Carsrud \& Brannback, 2011).

Drawing the relation between motivation and personality involves identifying the significant patterns of behaviour and linking them to the basic psychological processes of cognition, affect, traits and situation (Brandstatter, 2011; Dweck \& Leggett, 1988). The explanations of motivational processes centre on the differing behavioural patterns and the goals individuals pursue that have intrinsic and extrinsic value (Baron, 2001).

Dweck (1986), and Dweck and Leggett (1988) suggest a social cognitive theory of motivation and personality that explains different behavioural patterns of individuals. This motivational theory of personality views individuals in the two patterns of adapting to the task or maladapting to the task. The adaptive or the mastery-oriented pattern pertains to challenge-seeking and high effective persistence in the face of obstacles and the maladaptive or the helpless pattern 
pertains to challenge-avoidance and low persistence in the face of stumbling blocks (Dweck, 1986).

Explaining the motivational processes of these two different behavioural patterns, Dweck (1986), and Dweck and Leggett (1988) refer to two types of goals of 'performance' and 'learning' where the former implies individuals seeking to gain favourable judgements of their competence or avoiding negative judgements of their competence and the latter refers to seeking or understanding something new or challenging. Further, individuals set or choose these types of goals in accordance with their belief that intelligence is fixed (entity theory for performance goals) and intelligence is malleable (incremental theory for learning goals) and these implicit theories guide the behaviour of individuals in different paths (Dweck \& Leggett, 1988).

A related motivational theory called regulatory focus theory explains the differing motivational and strategic tendencies involved in the process of goal attainment (Brockner, Higgins, \& Low, 2004). Originally conceived by Higgins (as cited in Brockner et al., 2004), self-regulatory focus theory helps explain the entrepreneurial success/failure from the individual's own motivational dynamics where the focus is based on the well-established law of human behaviour that people seek to approach pleasure and avoid pain and this they do it in two different ways, one with a promotion focus and the other with a prevention focus (Brockner et al., 2004).

In the explanation of self-regulatory focus theory the cognitive-motivational framework of entrepreneurs are embedded with the personality system in which those with a prevention focus are concerned with protection, safety and responsibility as they are motivated to avoid losses or setbacks (Hmieleski \& Baron, 2008) and those who self-regulate through promotion are concerned with advancements and accomplishments as they are motivated to seek gains and new achievements (Hmieleski \& Baron, 2008).

According to both the regulatory focus theory and the implicit theory of growth orientation vs. fixed orientation (incremental theory vs. entity theory) individuals cognitively, affectively, motivationally and behaviourally side with avoiding pain and disapproval, or side with approaching pleasure and reward. The underlying tendency involves positioning oneself on the learning/promotion side or performing/preventing side which is clearly in relation to the activities chosen. 
Further, the "ideal self-guide" (Carver et al., 2000, p.744) is on the mastery-oriented path (Dweck, 1986) choosing learning goals and "oughts (self-guide)" (Carver et al., 2000, p.744) is on the defensive path (Dweck, 1986) choosing performance goals (Hmieleski \& Baron, 2008).

Accordingly, true entrepreneurs are individuals with a mastery-oriented pattern seeking learning goals as the environment that they are confronted with is conducive to experimenting with their malleable intelligence and seeking challenging or novel ways of doing things. Alternatively, individuals with promotion focus turn out to be true entrepreneurs as they are motivated to seek growth and achievements.

\section{Entrepreneurial Traits}

Trait approach to personality argues that there is a clear relation between stable inner dispositions and behavioural expressions of the same. The traits show crosssituational consistency even though it is not fully supported with empirical evidences (Dweck \& Legett, 1988; Mischel \& Shoda, 1995; Rauch \& Frese, 2007). Moreover, traits are dynamic; they undergo change, they evolve and they get modified in the process of interaction with the situation (Roberts, Walton, \& Viechtbauer, 2006).

In the light of the controversy that surrounds trait theories, entrepreneurial trait researchers differentiate between distal (broad) and proximal (specific) traits to account for the relation between entrepreneurial trait dispositions and entrepreneurial behaviours (Rauch \& Frese, 2007). The position entrepreneurial trait researchers hold is that there are meaningful relationships between some broad personality traits (biologically determined potentials) and business creation via specific personality traits of an evolved form and more specific dynamic parameters of the person like goals and strategies (Rauch \& Frese, 2007). Traits affect and the enactment of repeated behaviours result in the formation of a skill or habit where traits are the underlying tendencies of personality (Baum \& Locke, 2004). It is here that entrepreneurial trait research becomes significant as it focuses on the individual differences of entrepreneurs' personality dimensions, i.e. psychological drive states that differentiate them from non-entrepreneurs (Fernald, Solomon, \& Tarabishy, 2005). Moreover, recent research suggests (for example, Zhao et al., 2010) the influence of moderating variables in the link between trait dispositions and entrepreneurial performance. 
The emergence of the Big Five Factor Model of personality (McCrae \& Costa, 2008) has paved the way for a comprehensive, parsimonious and meaningful organisation of a group of personality traits (Zhao et al., 2010). This taxonomical approach to studying personality indicates positive relationship between the five traits and entrepreneurial activity. A meta-analytic study, conducted by Rauch and Frese (2007) shows that broad traits relate significantly to entrepreneurial success in a broad manner. Of the five traits, Zhao et al. (2010) report that conscientiousness, openness to experience, emotional stability and extraversion are positively related to intentions to become an entrepreneur and entrepreneurial performance. Further, according to Zhao et al. (2010), openness to experience and conscientiousness are the personality constructs strongly and consistently associated with entrepreneurial intentions and entrepreneurial performance.

Two other significant trait-oriented models are the MBTI and META. Based on the Jungian theory of personality, MBTI categorises individuals into four bipolar groups: extraversion-introversion, sensing-intuitive, thinking-feeling and judgingperceiving. Johnston, Andersen, Davidge-Pitts, and Ostensen-Saunders (2009) report that perceivers turn out to be adaptive entrepreneurs and intuitives are found to be innovative entrepreneurs. The second trait model called META - Measures of Entrepreneurial Tendencies and Abilities - refer to entrepreneurial proactivity, entrepreneurial creativity, entrepreneurial opportunism and entrepreneurial vision as the four components of entrepreneurship (Leutner et al., 2014).

Setting aside the influence of distal traits in the explanation of entrepreneurial personality, researchers now give importance to proximal traits or specific traits as these have good explanatory power in conjunction with other intra-individual mediators, situational variables and task specific factors of goals and self-efficacy (Baum \& Locke, 2004; Rauch \& Frese, 2007).

In discussing the proximal traits it is pertinent to point out that most of the studies on entrepreneurial personality use criterion validated concepts of personality rather than broad trait measures (Rauch \& Frese, 2007) and there is a general agreement among researchers on the specific pattern of traits that interact with entrepreneurial thinking, motivation, affect and behaviour (Brandstatter, 2011; Mischel \& Shoda, 1995; Obschonka \& Stuetzer, 2017)). Considering the propositions of researchers like Lumpkin and Dess (1996), Morris and Sexton (1996), Rauch and Frese (2007), and Vecchio (2003), the core proximal entrepreneurial traits that are considered to be significant in understanding 
entrepreneurial personality are risk-taking propensity, need for achievement, need for autonomy, innovativeness, proactiveness, internal locus of control and selfefficacy. Of these, need for achievement and need for autonomy are generally considered to be motivational constructs which mean that traits are also drive states (Brandstatter, 2011; Vecchio, 2003).

Combining the probability function and the individual disposition towards risktaking, Chell et al. (as cited in Rauch \& Frese, 2007), describe a risk-taker as someone who pursues a business idea when the probability of succeeding is low. In other words, decisions are risk-taking when the probability of failure or the cost of failure is moderate to high (Morris \& Sexton, 1996).

Innovativeness is the disposition to engage in and support new ideas, identifying novel ways of doing things and to indulge in creative processes producing new products, services or technological processes (Lumpkin \& Dess, 1996). Innovative orientation can be characterised by the disposition to experimentation and the tendency to process information and find new relationships.

Webster's dictionary defines proactiveness as "acting in anticipation of future problems, needs or changes" and this is accepted by entrepreneurial researchers (for instance, Lumpkin \& Dess, 1996, p.146). In relation to entrepreneurial activity proactivity implies anticipating and acting on future needs by seeking or exploring new opportunities and taking initiatives and planning to produce goods/services or initiating moves to confront the future which again can be in relation to market, strategy, price, technology or life style (Hahn, Frese, Binnewies \& Schmitt, 2011).

The construct of internal locus of control is the key to understanding one's beliefs and expectancies and the role of ability, effort and luck in creating outcomes. Rauch and Frese (2007) refer to a meta-analytic study that demonstrate positive and significant differences between owners' and non-owners' internal locus of control and positive correlation between internal locus of control and success. The dynamics of internal locus of control fashion the entrepreneur along the lines of perseverance.

Self-efficacy as a proximal trait of entrepreneurship characterises individuals with the general belief that they are capable of executing tasks of similar and dissimilar nature in comparison to individuals generally preferring to avoid 
situations over which the belief of executing a task is lacking. When these ideas are extended to entrepreneurship, it indicates that people with high entrepreneurial selfefficacy tend to engage in activities related to firm start-ups and perceive more opportunities in a given situation (Vecchio, 2003). High entrepreneurial selfefficacy further implies that such entrepreneurs are more confident with their ability to cope with perceived obstacles and to anticipate outcomes (Vecchio, 2003). Entrepreneurial self-efficacy explains why some individuals with abilities do not become entrepreneurs as they believe that they do not have such ability (Sanchez, Carballo, \& Gutiérrez, 2011).

In the CAPS theory version, traits are defined as "a characteristic cognitiveaffective processing structure that underlies and generates distinctive processing dynamics" (Mischel \& Shoda, 1995, p.257). These processing structures of cognition, affect and motivation in their dynamic interaction activate/deactivate certain patterns of behaviour in response to situational features. These entrepreneurial structures are now more than traits as they are derived from the configurational processes, where the CAMTS is in a state of dynamic interaction.

\section{Entrepreneurial Situation: An Interactive View}

Etymologically context implies weaving together or making a connection and "in management research context can refer to circumstances, conditions, situations or environments that are external to the respective phenomenon that enable or constrain it" (Welter, 2011, p.167). Context is important for understanding "when, how and why entrepreneurship happens and who becomes involved" (Welter, 2011, p.165) and Baumol (as cited in Welter, 2011, p.165), states that roles for entrepreneurship "do change dramatically from one time and place to another".

Welter (2011) refers to who, where and when dimensions of context and in the entrepreneurial context 'who' means "who enters entrepreneurship and which ventures are created" (Welter, 2011, p.167), 'where' refers to the milieu, the sociopolitical-economic-technological, spatial and institutional ambience of entrepreneurship and 'when' refers to temporal and historical processes that shape the entrepreneurial activities. Moreover, according to Pendergast (2003) entrepreneurial context is defined by opportunity orientation, unstructured, uncertain, scarce in resources, and fluid, dynamic and turbulent. Understanding entrepreneurial personality implies understanding the entrepreneurial context as there is no entrepreneurial success without the contextualization of the 
entrepreneurial process (Aldrich \& Martinez, 2001); in other words, the creation and discovery of opportunities are embedded with the context.

Entrepreneurial context is integral to personality in that its structure and functioning is an interactive outcome wherein the intra-individual processes differentially and in varying patterns establish reciprocal relations with the context (Bandura, 1999; Mischel \& Shoda, 1995). In the social cognitive theory of personality, the interaction is depicted as 'triadic reciprocal causation' that involves a dynamic interplay among the intra-individual processes, behaviour and environmental influences (Bandura, 1978).

The integration of entrepreneurial context in the entrepreneurial personality system further follows the discovery and creation theories of entrepreneurship. In the discovery theory of entrepreneurship, 'exogenous shocks' created in the entrepreneurial context are to be detected by entrepreneurs who are endowed with an entrepreneurial personality. The implication is that non-entrepreneurs are not necessarily discoverers. To differentiate an entrepreneur who is a discoverer from a non-entrepreneur, Kirzner (as cited in Alvarez \& Barney, 2007), refers to the concept of entrepreneurial alertness, an offshoot of the basic structure of entrepreneurial personality system, which is explained in terms of information asymmetries, different risk preferences and cognitive differences.

In creation theory, opportunities are endogenous phenomena where the entrepreneurial personality plays the dominant role and it is the interaction with the environment that produces the socially constructed opportunities. Creation and discovery theories place emphasis on the interaction between entrepreneur and the entrepreneurial context even though they differ on the source of opportunities. The source of opportunity in discovery theory is the environment and in the creation theory it is the entrepreneur himself.

The significance of the context in determining entrepreneurial personality is such that entrepreneurs are sometimes the 'victims' or the 'architects' of the context (Shoda \& Mischel, 2000). The essence of this process-dynamic interaction between the personality subsystems and context can be further understood in relation to the structuration theory perspective. The focus of structuration theory as enunciated by Giddens (as cited in Sarason et al., 2006), is the reciprocal interaction of individual entrepreneur and the context wherein the individual entrepreneurs are both enabled and constrained by structures. These structures can also take the form of symbolic 
representations as these structures are the result of past actions by individuals and are carried forward as memory traces (Sarason et al., 2006). According to the structuration theory of entrepreneurship (Sarason et al., 2006) information generated in the entrepreneurial situation follow a pattern of reciprocal relationship that they mutually influence each other and thereby cognitions are created or modified and environmental attributes are created or modified (Sarason et al., 2006).

A key aspect of structuration theory is reflexive monitoring (Giddens, as cited in Sarason et al., 2006). "Reflexivity refers to the capacity of humans to routinely observe and understand what they are doing while they are doing it" (Sarason et al., 2006, p.291). Besides, individuals continue to monitor the flow of their activities as they are able to monitor what they are monitoring (Sarason et al., 2006). In structuration theory perspective opportunities are not independent of the entrepreneur. Through the process of instantiation, at the moment of interaction with the context an "idiosyncratic rendering of information sets as 'facts' by an entrepreneur" creates an opportunity (Sarason et al., 2006, p.293).

The distinguishing feature of the structuration theory in relation to configurational analysis is that through reflexive monitoring and recursive relationship, the entrepreneur is able to modify the structures of the environment internally and externally as he reflects upon the structures which also change the individual's intra-individual subsystems producing different configurational patterns of EP (Sarason et al., 2006).

Thus, in the configurational analysis the situation interacts with the internal structures and processes wherein the five factors of CAMTS configure (Dess et al., 1993; Korunka et al., 2003) the entrepreneurial personality system such that intraindividual dynamic processes in interaction and mediation with the situation (Mischel \& Shoda, 1995) capture the nature of the entrepreneurial personality system.

\section{Summative Consideration: A Recasting of Specific Entrepreneurial Personality Structures}

In extending the value of the model, there is theoretical and empirical support to state that specific EP constructs such as entrepreneurial self-efficacy, entrepreneurial intention, entrepreneurial alertness, entrepreneurial orientation, entrepreneurial intensity and entrepreneurial passion are the offshoots of the general configurational structure. 
It is evident that these specific expressions are the elaborations of the entrepreneurial personality structure that are developed in the configurational dynamics. The significance of the configurational model as discussed in the previous two sections is that the CAMTS subsystems in their interactions and mediations produce different configurations of personality generally and specifically. The general EP configuration outlined above is the effect of the general configuration, which is the sum total of the personality that differentiates an entrepreneur from a non-entrepreneur. To outline the specific effects of the specific configurations, one has to go by the specific interactions and mediations of certain specific subsystems of CAMTS that exercise varying effects producing specific entrepreneurial personality structures that are similar to the general configuration in small measures as it shares the similarity with the sub-systems. In other words, the general structure and specific structures overlap in different ways as the contribution of each sub-system varies across sub-systems given that in the general structure no specific attention is given to a particular subsystem but what is emphasized is the overall contribution of all the subsystems in the configurational dynamics. In the specific configurational patterns each sub-system differentially influences a specific EP structure. Moreover, in the language of CAPS theory (Mischel \& Shoda, 1995), these influences can also be strong activation, weak activation or deactivation. Upon being activated or deactivated either by an external stimuli or internal stimuli the sub-systems trigger activating or deactivating related intra-individual structures and processes, and the net result of these influences is the configuration of a specific EP structure.

These entrepreneurial constructs differ among individual entrepreneurs as they can be differentiated by the specific dynamics of the sub-systems in its configuration. It is also to be noted that these conceptually distinct elaborations share some features with other constructs as they are inter-related and as they spring from the same CAMTS configurations. What makes a construct distinctive and independent is the fact that it is predominant in one or two sub-systems and/or other combinations thereof which is in keeping with the specific configuration model explained; each of these six structures is briefly explained.

Entrepreneurial intentions (EI) are defined as the conscious state of mind that directs personal attention, experience, interest and behaviour toward planned entrepreneurial activities (Obschonka, Silbereisen \& Schmitt-Rodermund, 2010) or 
defined as an informational search for fulfilling the goal of venture creation (Katz \& Gartner, as cited in Choo \& Wong, 2008), or orientations toward starting a business (Hmieleski \& Corbett, 2006).

In the specific configurational dynamics of EI, the knowledge structures and processes of entrepreneurial activities (Liñán, Rodríguez-Cohard, \& RuedaCantuche, 2011; Zhao, Seibert, \& Hills, 2005) and the affective states (Krueger, Reilly, \& Carsrud, 2000) exercise the predominant influence in its development. Personality traits like risk-taking propensity, internal locus of control, innovativeness and independence along with the situation in terms of the structural and educational practices and motivation play a role though weak in the development and configuration of EI (Turker \& Sonmez Selcuk, 2009).

High entrepreneurial self-efficacy, defined as an entrepreneur's high levels of belief in their capability to execute entrepreneurial tasks of new venture creation bring about high performance in entrepreneurial tasks (Forbes, 2005). Entrepreneurial self-efficacy as a cognitive/motivational personality construct is related to a person's system of beliefs in the realm of enacting task-related behaviours to start a new venture and it tells about the execution of innovative activities of entrepreneurs including improvisational behaviours (Hmieleski \& Corbett, 2008). As information processors individuals develop a sense of how capable they are in executing tasks (Barbosa, Gerhardt, \& Kickul, 2007). Besides the knowledge factor, the intuitive and the analytic cognitive styles of individuals influence the levels of self-efficacy wherein intuitive style is related with quick identification of entrepreneurial opportunities and analytics are good in assessing and planning tasks (Kickul, Gundry, Barbos, \& Whitcanack, 2009). In consideration of this it can be stated that along with motivation and cognition the situation (Barbosa et al., 2007) exercise strong influence on self-efficacy. Further, personality traits like risk propensity (Barbosa et al., 2007) and affect (Cardon \& Kirk, 2015) mediate the self-efficacy belief.

Another entrepreneurial personality construct derived from the entrepreneurial configurational personality system is entrepreneurial passion. It is defined as consciously accessible, intense pleasurable state of feeling experienced by individual entrepreneurs in their engagement with entrepreneurial activities that define their self-identity (Cardon, Wincent, Singh, \& Drnovsek, 2009). The construct of entrepreneurial passion adds to the understanding of EP dynamics as entrepreneurial passion draws upon the affective, cognitive, motivational and trait 
dimensions of personality (Cardon et al., 2009). Entrepreneurial passion further involves infusion of some idea into the mind and the drive to overcome barriers (Cardon et al., 2009).In relation to the pattern of the configuration, affect, cognition, motivation and traits exercises the strongest influence and situation weakly influence the nature of passion.

Entrepreneurial alertness, understood as a distinctive set of perceptual and cognitive processing skills involved in the opportunity identification (Gaglio\& Katz, 2001) differentiate an entrepreneur by positioning "oneself in the flow of information so that probability of encountering opportunities without a deliberate search for a specific opportunity is maximized" (Gaglio \& Katz, 2001, p.96). According to Kirzner (as cited in Gaglio \& Katz, 2001), credited with the introduction of the concept, the unique mental representations and interpretations and the motivational inclination to formulate 'an image of the future' make an entrepreneur alert. In relation to the pattern of the configurational dynamics, cognition has the strongest influence followed by a somewhat weaker influence of motivation, individual traits and situation (Gaglio \& Katz, 2001; Tang, Kacmar, \& Busenitz, 2012).

Entrepreneurial orientation originally proposed to explain the performance of firms can also be true of individual behaviour (Kollmann, Christofor, \& Kuckertz, 2007; Bolton \& Lane, 2012; Lumpkin \& Dess, 1996). The key five characteristics of entrepreneurial orientation as suggested by Lumpkin and Dess (1996) are also the orientation factors in individual entrepreneurial orientation. The entrepreneurial traits that define entrepreneurial orientation are competitive aggressiveness, innovativeness, proaction, risk-taking and autonomy seeking (Lyon, Lumpkin, \& Dess, 2000). In relation to the configurational dynamics cognition, motivation, affect and personality traits exercise a major influence and situation exercise a weak influence (Bolton \& Lane, 2012).

Finally, entrepreneurial intensity as explained by Morris and Sexton (1996) is constitutive of the degree and frequency of entrepreneurship wherein the degree is made up of risk-taking, innovativeness and proactivity and the frequency implies the number of entrepreneurial outcomes that an entrepreneur is able to produce in a given period. In the configurational effect, the personality traits of risk-taking, innovativeness and proactivity, and the situation influence in a strong way in the development of entrepreneurial intensity (Morris \& Sexton, 1996). In other words, 
all sub-systems of CAMTS exercise a strong influence in the development of entrepreneurial intensity.

\section{Conclusion}

The conventional EP research focuses on correlational and unidirectional influences of personality on entrepreneurship wherein an assortment of personality traits are related with isolated EP characteristics. A greater understanding of the construct is embedded with the intra-individual processes and dynamics that differentiate entrepreneurs from non-entrepreneurs in an entrepreneurial context wherein the context too exercises a significant influence in the interactive and reciprocal determination of personality. The general and the specific Configurational Models of Entrepreneurial Personality presented in this paper indicate how the basic psychological structures and processes of CAMTS shape up the distinctive entrepreneurial personality in different patterns. The configuration that takes shape, which is contingent on an individual's uniqueness and subjectivity and the situation differentiate an entrepreneurial personality generally and specifically. The distinctive cognitive, affective, motivational, trait and situational dynamics configure the pattern of an entrepreneurial personality. For example, in instances where an overwhelming subsystem like affect, predominate in the configurational dynamics, a specific entrepreneurial personality structure like entrepreneurial passion develops in the behavioural repertoire. In this multiple interactions, besides characterising the general entrepreneurial personality structure, specific elaborations of entrepreneurial personality constructs can be explained and the existence of new constructs can be hypothesised.

The configurational model of entrepreneurial personality thus explains the general and the specific entrepreneurial personality structures contributing to the understanding of the construct and this improves the predictive and the explanatory power of the model. The CAMTS configurational model of EP in its broad-based and specific applications account for the variance and the invariance observed among entrepreneurs and between entrepreneurs and non-entrepreneurs. It explains how an EP comes about in the interactional processes of intra-individual subsystems including the context. The model is also capable of deriving further EP structures as life of an entrepreneur or a would-be entrepreneur becomes complex and uncertain.

\section{Declaration of Conflicting Interests}

The author declared no potential conflicts of interest with respect to the research, authorship, and publication of this article. 


\section{Acknowledgements}

The author expresses his gratitude to the anonymous reviewers for their constructive suggestions to improve the quality of the paper.

\section{References}

Aldrich, H. E., \& Martinez, M. A. (2001). Many are called, but few are chosen: An evolutionary perspective for the study of entrepreneurship. Entrepreneurship Theory and Practice, 25(4), 41-56. doi:10.1177/104225870102500404

Alvarez, S. A., \& Barney, J. B. (2007). Discovery and creation: Alternative theories of entrepreneurial action. Strategic Entrepreneurship Journal, 1(1-2), 11-26. doi:10.1002/sej.4

Bandura, A. (1978). The self system in reciprocal determinism. American Psychologist, 33(4), 344-358. doi:10.1037/0003-066X.33.4.344

Bandura, A.(1999). A social cognitive theory of personality. In D.Cervone \& Y. Shoda (Eds.), The coherence of personality: Social cognitive bases of consistency, variability and organization, (pp-185-241). New York: Guilford Press

Barbosa, S. D., Gerhardt, M. W., \& Kickul, J. R. (2007). The role of cognitive style and risk preference on entrepreneurial self-efficacy and entrepreneurial intentions. Journal of Leadership \& Organizational Studies, 13(4), 86-104. doi:10.1177/10717919070130041001

Baron, R.A. (2001). Psychology (5 ${ }^{\text {th }}$ ed.), New Delhi: Pearson Education

Baron, R. A. (2008). The role of affect in the entrepreneurial process. Academy of Management Review, 33(2), 328-340. doi:10.5465/AMR.2008.31193166

Baron, R. A., \& Ward, T. B. (2004). Expanding entrepreneurial cognition's toolbox: Potential contributions from the field of cognitive science. Entrepreneurship Theory and Practice, 28(6), 553-573. doi:10.1111/j.1540-6520.2004.00064

Baum, J. R., \& Locke, E. A. (2004). The relationship of entrepreneurial traits, skill, and motivation to subsequent venture growth. Journal of Applied Psychology, 89(4), 587-598. doi:10.1037/0021-9010.89.4.587

Bernard, L. (2016). The action-trait theory of motivation: A commentary on Roy F. Baumeister's 2014 address to the Society for the Study of Motivation. Motivation and Emotion, 40(1), 22-26. doi:10.1007/s11031-015-9537-3

Bolton, D. L., \& Lane, M. D. (2012). Individual entrepreneurial orientation: Development of a measurement instrument. Education + Training, 54(2/3), 219-233. doi:10.1108/00400911211210314

Brandstätter, H. (2011). Personality aspects of entrepreneurship: A look at five meta-analyses. Personality and individual differences, 51(3), 222- 230. doi:10.1016/j.paid.2010.07.007 
Brockner, J., Higgins, E. T., \& Low, M. B. (2004).Regulatory focus theory and the entrepreneurial process. Journal of Business Venturing, 19(2), 203-220. doi:10.1016/S0883-9026(03)00007-7

Cardon, M. S., Foo, M. D., Shepherd, D., \& Wiklund, J. (2012). Exploring the heart: Entrepreneurial emotion is a hot topic. Entrepreneurship Theory and Practice, 36(1), 1-10. doi:10.1111/j.1540-6520.2011.00501.x

Cardon, M. S., \& Kirk, C. P. (2015). Entrepreneurial passion as mediator of the selfefficacy to persistence relationship. Entrepreneurship Theory and Practice, 39(5), 1027-1050. doi:10.1111/etap.12089

Cardon, M. S., Wincent, J., Singh, J., \& Drnovsek, M. (2009).The nature and experience of entrepreneurial passion. Academy of Management Review, 34(3), 511-532. doi:10.5465/AMR.2009.40633190

Carsrud, A., \& Brännback, M. (2011). Entrepreneurial motivations: What do we still need to know? Journal of Small Business Management, 49(1), 9-26. doi:10.1111/j.1540-627x.2010.00312.x

Carver, C. S., Sutton, S. K., \& Scheier, M. F. (2000). Action, emotion, and personality: Emerging conceptual integration. Personality and Social Psychology Bulletin, 26(6), 741-751. doi:10.1177/0146167200268008

Chell, E. (2008). The entrepreneurial personality: A social construction ( $2^{\text {nd }}$ ed.). London: Routledge.

Choo, S., \& Wong, M. (2006). Entrepreneurial intention: Triggers and barriers to new venture creations in Singapore. Singapore Management Review, 28(2), $47-$ 64

Connell, J. P., Halpem-Felsher, B. L., Clifford, E., Crichlow, W., \& Usinger, P. (1995). Hanging in there: Behavioral, psychological, and contextual factors affecting whether African American adolescents stay in high school. Journal of Adolescent Research, 10(1), 41-63. doi:10.1177/0743554895101004

Dauber, D., Fink, G., \& Yolles, M. (2012). A configuration model of organizational culture. SAGE Open, 2(1), 1-15. doi:10.1177/2158244012441482

De Shon, R. P., \& Gillespie, J. Z. (2005). A motivated action theory account of goal orientation. Journal of Applied Psychology,90(6), 1096-1127. doi:10.1037/0021-9010.90.6.1096

Dess, G. G., Newport, S., \& Rasheed, A. M. (1993). Configuration research in strategic management: Key issues and suggestions. Journal of Management, 19(4), 775-795. doi:10.1177/014920639301900403

Dweck, C. S. (1986). Motivational processes affecting learning. American Psychologist, 41(10), 1040-1048. doi:10.1037/0003-066X.41.10.1040

Dweck, C. S., \& Leggett, E. L. (1988). A social-cognitive approach to motivation and personality. Psychological Review, 95(2), 256-273. doi:10.1037/0033295X.95.2.256 
Fernald, L. W., Jr., Solomon, G. T., \& Tarabishy, A. (2005). A new paradigm: Entrepreneurial leadership. Southern Business Review, 30(2), 1-10.

Forbes, D. P. (2005). The effects of strategic decision making on entrepreneurial self-efficacy. Entrepreneurship Theory and Practice, 29(5), 599-626. doi:10.1111/j.1540-6520.2005.00100.x

Gaglio, C. M., \& Katz, J. A. (2001). The psychological basis of opportunity identification: Entrepreneurial alertness. Small Business Economics, 16(2), 95111. doi:10.1023/A:1011132102464

Goss, D. (2008). Enterprise ritual: A theory of entrepreneurial emotion and exchange. British Journal of Management, 19(2), 120-137. doi:/10.1111/j.1467-8551.2006.00518.x

Hahn, V. C., Frese, M., Binnewies, C., \& Schmitt, A. (2012). Happy and proactive? The role of hedonic and eudaimonic well-being in business owners' personal initiative. Entrepreneurship Theory and Practice,36(1), 97-114. doi:10.1111/j.1540-6520.2011.00490.x

Hmieleski, K. M., \& Baron, R. A. (2008). Regulatory focus and new venture performance: A study of entrepreneurial opportunity exploitation under conditions of risk versus uncertainty. Strategic Entrepreneurship Journal, 2(4), 285-299. doi:10.1002/sej.56

Hmieleski, K. M., \& Corbett, A. C. (2006). Proclivity for improvisation as a predictor of entrepreneurial intentions. Journal of Small Business Management, 44(1), 45-63. doi:10.1111/j.1540-627x.2006.00153.xd

Hmieleski, K. M., \& Corbett, A. C. (2008). The contrasting interaction effects of improvisational behavior with entrepreneurial self-efficacy on new venture performance and entrepreneur work satisfaction. Journal of Business Venturing, 23(4), 482-496. doi:10.1016/j.jbusvent.2007.04.002

Homburg, C., Koschate, N., \& Hoyer, W. D. (2006). The role of cognition and affect in the formation of customer satisfaction: A dynamic perspective. Journal of Marketing, 70(3), 21-31. doi:10.1509/jmkg.70.3.21

Hunter, J. A., \& Schmidt, F. L. (1990). Methods of meta-analysis. Newbury Park, CA: Sage.

Johnston, K. A., Andersen, B. K., Davidge-Pitts, J., \& Ostensen-Saunders, M. (2009). Identifying student potential for ICT entrepreneurship using MyersBriggs personality type indicators. Journal of Information Technology Education, 8(1), 29-43. doi:10.28945/156

Kickul, J., Gundry, L. K., Barbosa, S. D., \& Whitcanack, L. (2009). Intuition versus analysis? Testing differential models of cognitive style on entrepreneurial selfefficacy and the new venture creation process. Entrepreneurship theory and practice, 33(2), 439-453. doi:10.1111/j.1540-6520.2009.00298.x 
Kollmann, T., Christofor, J., \& Kuckertz, A. (2007). Explaining individual entrepreneurial orientation: Conceptualization of a cross-cultural research framework. International Journal of Entrepreneurship and Small Business, 4(3), 325-340. doi:10.1504/IJESB.2007.013255

Korunka, C., Frank, H., Lueger, M., \&Mugler, J. (2003). The entrepreneurial personality in the context of resources, environment, and the startup process - A configurational approach. Entrepreneurship Theory and Practice, 28(1), 23-42. doi:10.1111/1540-8520.00030

Krueger, N. F., Jr., Reilly, M. D., \& Carsrud, A. L. (2000). Competing models of entrepreneurial intentions. Journal of Business Venturing, 15(5-6), 411-432. doi:10.1016/s0883-9026(98)00033-0d

Lazarus, R. S. (1991) Cognition and motivation in emotion. American Psychologist 46, 352-367. doi:10.1037//0003-066x.46.4.352

Leutner, F., Ahmetoglu, G., Akhtar, R., \& Chamorro-Premuzic, T. (2014). The relationship between the entrepreneurial personality and the Big Five personality traits. Personality and Individual Differences, 63, 58-63. doi:10.1016/j.paid.2014.01.042

Levy, O., Beechler, S., Taylor, S., \& Boyacigiller, N. A. (2007). What we talk about when we talk about 'global mindset': Managerial cognition in multinational corporations. Journal of International Business Studies, 38(2), 231-258. doi:10.1057/palgrave.jibs.8400265

Liñán, F., Rodríguez-Cohard, J. C., \& Rueda-Cantuche, J. M. (2011). Factors affecting entrepreneurial intention levels: A role for education. International Entrepreneurship and Management Journal,7(2), 195-218. doi:10.1007/s11365-010-0154-z

Lumpkin, G. T., \& Dess, G. G. (1996). Clarifying the entrepreneurial orientation construct and linking it to performance. Academy of Management Review, 21(1), 135-172. doi:10.2307/258632d

Lyon, D. W., Lumpkin, G. T., \& Dess, G. G. (2000). Enhancing entrepreneurial orientation research: Operationalizing and measuring a key strategic decision making process. Journal of Management, 26(5), 1055-1085. doi:10.1177/014920630002600503

Matthews, G. (2016). Traits, cognitive processes and adaptation: An elegy for Hans Eysenck's personality theory. Personality and Individual Differences, 103, 6167. doi:10.1016/j.paid.2016.04.037

Madhavaram, S., Badrinarayanan, V., \& Granot, E. (2011). Approaching global industrial marketing from a managerial cognition perspective: A theoretical framework. Journal of Business \& Industrial Marketing, 26(7), 532-541. doi:10.1108/08858621111162334 
McCrae, R. R., \& Costa, P. T. Jr. (2008). The five-factor theory ofpersonality. In O. P. John, R. W. Robins, \& L. A. Pervin (Eds.), Handbook of personality: Theory and research ( $3^{\text {rd }}$ ed., pp. 159-181). NY: Guilford Press.

Meyer, A. D., Tsui, A. S., \& Hinings, C. R. (1993). Configurational approaches to organizational analysis. Academy of Management Journal, 36, 1175-1195. doi: $10.5465 / 256809$

Miller, D. (1987). The genesis of configuration. Academy of Management Review, 12(4), 686-701. doi:10.2307/258073

Mischel, W., \& Shoda, Y. (1995). A cognitive-affective system theory of personality: Reconceptualizing situations, dispositions, dynamics, and invariance in personality structure. Psychological Review, 102(2), 246-268. doi:10.1037/0033-295X.102.2.246

Mitchell, R. K., Busenitz, L. W., Bird, B., Gaglio, M. C., McMullen, J. S., Morse, E. A., \& Smith, J. B. (2007). The central question in entrepreneurial cognition research 2007. Entrepreneurship Theory and Practice,31(1), 1-27. doi:10.1111/j.1540-6520.2007.00161.x

Mitchell, R. K., Smith, B., Seawright, K. W., \& Morse, E. A. (2000). Cross-cultural cognitions and the venture creation decision. Academy of Management Journal, 43(5), 974-993. doi:10.5465/1556422

Morris, M. H., Kuratko, D. F., Schindehutte, M., \& Spivack, A. J. (2012). Framing the entrepreneurial experience. Entrepreneurship Theory and Practice, 36(1), 11-40. doi:10.1111/j.1540-6520.2011.00471.x

Morris, M. H., \& Sexton, D. L. (1996). The concept of entrepreneurial intensity: Implications for company performance. Journal of Business Research, 36(1), 513. doi:10.1016/0148-2963(95)00158-1

Neisser, U. (1967). Cognitive psychology. New York: Appleton-Century-Crafts.

Obschonka, M., Silbereisen, R. K., \& Schmitt-Rodermund, E. (2010). Entrepreneurial intention as developmental outcome. Journal of Vocational Behavior, 77(1), 63-72. doi:10.1016/j.jvb.2010.02.008

Obschonka, M., \&Stuetzer, M. (2017). Integrating psychological approaches to entrepreneurship: The Entrepreneurial Personality System (EPS). Small Business Economics, 49,203-231. doi:10.1007/s11187-016-9821-y

Østergaard, A. (2014), Thechallenges of measuring the entrepreneurial personality? A methodological approach. Paper presented at the DRUID Society Conference 2014. Copenhagen: CBS.

Pendergast, W. R. (2003). Entrepreneurial contexts and traits of entrepreneurs. Proceedings of Teaching Entrepreneurship to Engineering Students: Engineering Conferences International, ECI Symposium Series, 2, 1-13. 
Roberts, B. W., Walton, K. E., \& Viechtbauer, W. (2006). Patterns of mean-level change in personality traits across the life course: A meta-analysis of longitudinal studies. Psychological bulletin, 132,(1), 1-25. doi:10.1037/00332909.132.1.1

Rauch, A., \& Frese, M. (2007). Born to be an entrepreneur? Revisiting the personality approach to entrepreneurship. In J. R. Baum, M. Frese, \& R. A. Baron (Eds.), Thepsychology of entrepreneurship (pp. 41-65). Mahwah, NJ: Erlbaum.

Sánchez, J. C., Carballo, T., \& Gutiérrez, A. (2011). The entrepreneur from a cognitive approach. Psicothema, 23(3), 433-438.

Sarason, Y., Dean, T., \& Dillard, J. F. (2006). Entrepreneurship as the nexus of individual and opportunity: A structuration view. Journal of Business Venturing, 21(3), 286-305. doi:10.1016/j.jbusvent.2005.02.007

Schneider, S. C., \& Angelmar, R. (1993). Cognition in organizational analysis: Who's minding the store? Organization Studies, 14(3), 347-374. doi:10.1177/ 017084069301400302

Schunk, B. J., \& Zimmerman, B. J. (1994). Self-regulation in education: Retrospect and prospect. In D. H. Schunk \& B. J. Zimmerman (Eds.), Self-regulation of learning and performance: Issues and educational applications (pp. 305-314). Hillsdale, NJ: Erlbaum.

Shane, S., \& Venkataraman, S. (2000). The promise of entrepreneurship as a field of research. Academy of Management Review, 25(1), 217-226. doi:10.2307/ 259271

Shoda, Y., \& Mischel, W. (2000). Reconciling contextualism with the core assumptions of personality psychology. European Journal of Personality, 14,407-428. doi:10.1002/1099-0984(200009/10)14:5<407::AIDPER391> 3.0. $\mathrm{CO} ; 2-3$

Tang, J., Kacmar, K. M. M., \& Busenitz, L. (2012). Entrepreneurial alertness in the pursuit of new opportunities. Journal of Business Venturing, 27(1), 77-94. doi:10.1016/j.jbusvent.2010.07.001

Turker, D., \& Sonmez Selçuk, S. (2009). Which factors affect entrepreneurial intention of university students? Journal of European industrial training, 33(2), 142-159. doi:10.1108/03090590910939049

Vaghely, I. P., \& Julien, P. A. (2010). Are opportunities recognized or constructed? An information perspective on entrepreneurial opportunity identification. Journal of Business Venturing,25(1), 73-86. doi:10.1016/ j.jbusvent.2008.06.004 
Vecchio, R. P (2003). Entrepreneurship and leadership: Common trends and common threads. Human Resource Management Review, 13(2), 303-327. doi:10.1016/S1053-4822(03)00019-6

Wegge, J., Dick, R. V., Fisher, G. K., West, M. A., \& Dawson, J. F. (2006). A test of basic assumptions of affective events theory (AET) in call centre work. British Journal of Management, 17(3), 237-254. doi:10.1111/j.14678551.2006.00489.x

Weiss, H. M., \& Cropanzano, R. (1996). Affective events theory: A theoretical discussion of the structure, causes and consequences of affective experiences at work. Research in Organizational Behavior, 18, 1-74.

Weiss, H. M., \& Cropanzano, R. (1996). Affective Events Theory: A theoretical discussion of the structure, causes and consequences of affective experiences at work. In B. M. Staw \& L. L. Cummings (Eds.), Research in organizational behavior: An annual series of analytical essays and critical reviews, (Vol. 18, pp. 1-74). US: Elsevier Science/JAI Press.

Welter, F. (2011). Contextualizing entrepreneurship - conceptual challenges and ways forward. Entrepreneurship Theory and Practice,35(1), 165-184. doi:10.1111/j.1540-6520.2010.00427.x

Winter, D. G., John, O. P., Stewart, A. J., Klohnen, E. C., \& Duncan, L. E. (1998). Traits and motives: Toward an integration of two traditions in personality research. Psychological Review, 105(2), 230-250. doi:10.1037/0033-295X. 105.2.230

Wolfe, M. T., \& Shepherd, D. A. (2015). "Bouncing back" from a loss: Entrepreneurial orientation, emotions, and failure narratives. Entrepreneurship Theory and Practice, 39(3), 675-700. doi:10.1111/etap.12057

Zhao, H., Seibert, S. E., \& Hills, G. E. (2005). The mediating role of self-efficacy in the development of entrepreneurial intentions. Journal of applied psychology, 90(6), 1265-1272. doi:10.1037/0021-9010.90.6.1265

Zhao, H., Seibert, S. E., \& Lumpkin, G. T. (2010). The relationship of personality to entrepreneurial intentions and performance: A meta-analytic review. Journal of Management, 36(2), 381-404. doi:10.1177/0149206309335187 